\section{Waste of Carbon and of Energy in Nitrogen Excretion}

IT is commonly accepted that, in nitrogen excretion, urea - and more especially uric acid-are wasteful to the organism in that they involve the loss of carbon and, moreover, chemical energy (see, for example, Needham ${ }^{1}$ ). Compared with ammonia, these substances are regarded as inefficient and as only resorted to under the exigencies of water conservation. Table 1 summarizes data from the literature, from which it is seen that, per nitrogen atom, the order of carbon waste (column c) is :

ammonia < urea < uric acid (or $0 ; 0.5 ; 1.25$ ).

But the amounts involved are scarcely significant; for example, for a man to excrete $30 \mathrm{gm}$. urea plus $0.7 \mathrm{gm}$. uric acid per day (Starling ${ }^{2}$ ) means the loss of $6.25 \mathrm{gm}$. carbon, which can be made up by the intake of $15.6 \mathrm{gm}$. glucose or equivalent. Similar calculations may be made for other non-ammonotelic animals.

In considering the energy factor, Needham quotes heat of combustion values for these three nitrogenous compounds in kcal./mole (column $d$ ), where the waste is in the order :

ammonia < urea < uric acid (or $1: 1 \cdot 69: 5 \cdot 11$ ) ; but it will be more pertinent to examine the figures for kcal./mole/nitrogen atom (column e), in which case the heat of combustion values appear in the order :

urea < ammonia < uric acid (or $1: 1 \cdot 18: 1 \cdot 51$ ).

However, it may be considered that the free energy of formation gives a truer indication of the energy relationships to the organism, and the order for these values is :

ammonia < urea < uric acid (or $1: 7 \cdot 73: 14 \cdot 52$ ), when calculated as kcal./mole (column $f$ ), and ammonia < uric acid < urea (or $1: 3 \cdot 63: 3 \cdot 87$ ), when calculated as kcal./mole/nitrogen atom (column $g$ ).

\section{Table 1}

\begin{tabular}{|c|c|c|c|c|c|c|}
\hline$a$ & $b$ & $c$ & $d^{*}$ & $e$ & $f \dagger$ & $g$ \\
\hline & $\begin{array}{l}\text { Empirical } \\
\text { formula }\end{array}$ & $\underset{\mathrm{C} / \mathrm{N}}{\text { Ratio }}$ & $\begin{array}{c}-\triangle H \\
\text { Heat of } \\
\text { combustion } \\
\text { (kcal./mole) }\end{array}$ & $\begin{array}{c}\text { Heat of } \\
\text { combustion } \\
\text { (kcal./mole/ } \\
\mathrm{N} \text { atom) }\end{array}$ & $\begin{array}{c}-\triangle G \\
\begin{array}{c}\text { Free energy } \\
\text { of formation } \\
\text { (kcal./mole) }\end{array}\end{array}$ & $\begin{array}{c}\text { Free energy } \\
\text { of formatlon } \\
\text { (kcal./mole/ } \\
\mathrm{N} \text { atom) }\end{array}$ \\
\hline $\begin{array}{l}\text { Ammonia } \\
\text { Urea } \\
\text { Uric acid }\end{array}$ & $\begin{array}{l}\mathrm{NH}_{3} \\
\mathrm{CON}_{2} \mathrm{H}_{4} \\
\mathrm{C}_{5} \mathrm{O}_{8} \mathrm{~N}_{4} \mathrm{H}_{4}\end{array}$ & $\begin{array}{l}\overline{0 \cdot 5} \\
1 \cdot 25\end{array}$ & $\begin{array}{r}90 \\
152 \\
460\end{array}$ & $\begin{array}{r}90 \\
76 \\
115\end{array}$ & $\begin{array}{c}6 \cdot 3 \\
48 \cdot 7 \\
91 \cdot 46\end{array}$ & $\begin{array}{c}6 \cdot 3 \\
24 \cdot 4 \\
22 \cdot 87\end{array}$ \\
\hline
\end{tabular}

* The figures in column $d$ are given in Needham as cal./mole, but they should obviously read kcal./mole.

t The flgures in column $f$ refer to the aqueous state for ammonia (Partington, ref. 3) and for urea (Parks and Huffman, ref. 4); the figure for uric acid is for the solid state will be slightly reduced.

Thus it may be concluded that: (i) ammonia is the most advantageous from the point of view of economy in carbon and in energy (except slightly in $-\Delta H$ calculated per nitrogen atom); (ii) urea wastes less carbon than does uric acid, but the amount is unlikely to be significant in either case; (iii) urea is approximately as wasteful as uric acid, and both are somewhat more wasteful than ammonia, in terms of $-\Delta G$ calculated per nitrogen atom, but the waste of chemical energy is not nearly as great as is generally implied.

It is suggested that the question of which nitrogenous end-product is resorted to may still be con- sidered as depending on the sbundance of the water supply of the organism, but that urea and uric acid excretion are not as disadvantageous as is sometimes expressed in the literature. Any disadvantage in terms of carbon and energy waste is far outweighed by the advantages conferred by ureo- or urico-tely.

Biology Department,

Canterbury University College,

Christchurch, C.1, New Zealand. Nov. 11.

1 Needham, J., "Chemical Embryology", 2, 1137 (Camb. Univ. Press, 1931).

2 Starling, E. H., "Principles of Human Physiology", 10th edit., revised by C. Lovatt Evans, 984 (Churchill, London, 1949).

Partington, J. R., "An Advanced Treatise on Physical Chemistry", 1, 225 (Longmans, London, 1949).

4 Parks, G. S., and Huffman, H. M., "The Free Energies of Some Organic Compounds", 187 (New York : Amer. Chem. Soc., Mon. Series, 1932).

\section{Stimulation of Certain Bacteria by Raw Milk}

AlthougH raw milk contains bacteriostatic substances, certain concentrations of it actually stimulate some micro-organisms such as Streptococcus agalactiae and Str. lactis ${ }^{1}$. Since the bacteriostatic properties appear fairly constant ${ }^{2}$, variations in stimulatory properties may account for the observations of seasonal variation in the growth-rate of microorganisms in milk ${ }^{\mathbf{3}}$.

Using cows infected in one or more quarters of the udder with mastitis, it has been found that milk from infected quarters is more stimulatory to Str. agalactiae than milk from non-infected quarters of the same udder.

Colostrum taken just before cows calved had a very high stimulatory effect, whereas just after calving the effect was much less. This is interesting, as it is known that cows are more susceptible to mastitis during the dry period.

A range of amino-acids and growth-factors was examined to discover whether any had stimulatory properties like those of raw milk. Only certain sulphur compounds gave positive results. Sodium sulphide and thioglycollic acid were stimulatory at concentrations down to $10^{-3} \mathrm{M}$; cystine and cysteine were still effective at $10^{-5} M$. Sodium sulphate was without effect.

It is suggested, therefore, that the concentration of certain sulphur compounds normally present in traces in milk affects markedly the rate of growth of some micro-organisms. The same factor may also control the susceptibility of cows to mastitis.

This work, which was carried out during the tenure of a British Council Scholarship at the National Institute for Research in Dairying, was part of an investigation on the inhibitory and stimulatory properties of milk.

\section{Station Centrale de Microbiologie}

J. E. Auclair et Recherches Laitières,

Institut National de la Recherche Agronomique, Paris.

Nov. 16.

1 Auclair, J. F., and Hirsh, A., J. Dairy Res., 20, 45 (1953).

2 Auclair, J. E., thesis, University of Reading (1953).

${ }^{3}$ Czulak, J., and Meanwell, L. J., Proc. Soc. App. Bact., 14, 1 (1951). 